Cameroon, Mr. Eteki Mboumoua and that of the President of the Cameroon Red Cross, Mr. S. Pierre Tchoungui.

The ICRC was represented by Mr. Chappuis, Delegate-General for Africa, Mr. Rigopoulo, Regional Delegate based in Lagos, and Mr. Siegenthaler, legal delegate, Operational Activities. The Henry Dunant Institute had delegated Mr. Toman, Interim Director.

The subjects dealt with were successively introduced by sixteen speakers, most of them African. The working meetings enabled African representatives from various nations to discuss problems of humanitarian law, compare the applications of that law in different countries and rediscover the universal character of the principles of humanitarian law, many of which are echoed by African traditions. In this respect, the seminar recommended that a global study be undertaken of African humanitarian traditions and of their interaction with international humanitarian law "as a means of promoting a better understanding and acceptance of humanitarian law by African Societies, States and Peoples".

The seminar, conducted in English and French, took place in excellent conditions and received special attention from the local press. It was the subject of radio and television broadcasts, including interviews with various speakers and participants.

The work of the seminar, the high level of which was repeatedly stressed, once again benefited from a wide range of skills displayed by participants from diverse backgrounds and representing a variety of disciplines. Such diversity fosters fruitful exchanges of views and valuable contacts, while at the same time bringing to the work of this type of seminar new ideas and possibilities depending on the outlook, experience and main concerns of each participant.

Participants were unanimous in expressing the desire to see these seminars continue on a regular basis.

\title{
A great promoter of Henry Dunant's message is no more
}

Mr. Jakob Haug, founder of the Henry Dunant Museum in Heiden, has passed away at the age of 87 . With him disappears one of the most engaging figures in the twentieth-century history of the 
Red Cross, for to say that his whole life was devoted to promoting Henry Dunant's message is an understatement.

In his youth, he met Henry Dunant in Heiden (the village where the founder of the Red Cross spent the last years of his life) and, fascinated by his personality, positively worshipped him to the day of his death.

While President of the Heiden Historical Society, Jakob Haug was instrumental in causing a monument to be erected to the memory of Henry Dunant. The monument which was inaugurated on 28 October 1962 is the work of Charlotte Germann-Jahn and is one of the most significant works to commemorate Henry Dunant.

Unflagging in his efforts to make Henry Dunant's life and thought better known in Switzerland, Jakob Haug founded a museum dedicated to him. In addition to various personal belongings (armchair, walking stick, hat, etc.) of the author of $A$ Memory of Solferino, the museum's collection includes manuscripts, photocopies of documents, the draft statutes of a Swiss league of human rights - the broad lines of which are taken up again in the Universal Declaration of Human Rights - and Dunant's letters to his friend Rudolf Müller who did so much for his rehabilitation. Reference is made to many famous people such as Dr. Altherr, Sonderegger, Baumberger, the Grand Duchess Maria Federovna, Basting and Daae who, like Müller, pleaded Dunant's cause.

In 1975, as a token of its gratitude for his tireless work to keep alive Dunant's memory, the ICRC awarded Jakob Haug its silver medal.

Mr. Haug funeral, on 10 January 1987, was attended by Mr. H.-P. Gasser, Legal Adviser to the Directorate, representing the President of the ICRC. The Swiss Red Cross was represented by Mr. J. Pascalis, Deputy Secretary General. The German Red Cross in the Federal Republic of Germany (Baden-Württemberg chapter) sent a delegation.

As Mr. Gasser said in his funeral oration: "The ICRC is and always will be grateful to Jakob Haug for the work he accomplished; as a result of his dedication, Heiden bears witness to Dunant's work and thereby to the very concept of the Red Cross"-a testimony which reaches far beyond the village where the founder of the Red Cross spent the last years of his life. 